\title{
SHORT PAPER \\ Survival of Shiga toxin-producing Escherichia coli 0157 in marine water and frequent detection of the Shiga toxin gene in marine water samples from an estuary port
}

\author{
K. MIYAGI ${ }^{1,2 *}, \mathrm{~K}$ OMURA ${ }^{2}$, A. OGAWA ${ }^{2}$, M. HANAFUSA ${ }^{2}$, Y. NAKANO $^{2}$, \\ S. MORIMATSU ${ }^{1}$ AND K. SANO ${ }^{1}$ \\ ${ }^{1}$ Department of Microbiology, Osaka Medical College, Takatsuki-shi, 569-8686, Japan \\ ${ }^{2}$ Osaka Quarantine Station, Osaka-shi 552-0021, Japan
}

(Accepted 17 October 2000)

\section{SUMMARY}

Shiga toxin-producing Escherichia coli (STEC) O157 was investigated with respect to its halotolerance and whether it can survive in marine water. STEC O157 could multiply in a medium containing $5 \% \mathrm{NaCl}$ and in sterilized marine water, and could survive in unsterilized marine water for at least 15 days. On the basis of these results, we postulated that STEC O157 may survive in natural marine water, and attempted to isolate the bacterium and Shiga toxin gene $(s t x)$ from marine water in Japan. The $s t x$, comprising $s t x_{1}$ and $s t x_{2}$, was detected from marine water samples by PCR. STEC and other stx-positive bacteria, however, could not be isolated from these samples in this study. These results indicate that $s t x$-positive bacteria may survive in marine water and suggest the necessity of a survey.

Shiga toxin-producing Escherichia coli (STEC; synonyms: verotoxin-producing E. coli (VTEC) and enterohaemorrhagic E. coli (EHEC)) is the causative agent of a dysentery-like diarrhoea and, rarely, also causes haemolytic uraemic syndrome (HUS) [1]. STEC is characterized by the production of Shiga toxin 1 (Stx1) and/or Shiga toxin 2 (Stx2). The transmission route of the bacterium is through food, such as contaminated beef [2], apple juice [3], vegetables [4], salmon roe in soy [5], and water [6, 7]. The natural hosts of the bacterium are domestic animals $[8,9]$ and the bacteria have also been found in water samples from lakes [10-12], pools [13, 14], and rivers [15]. Since faecally contaminated coastal water might pose a major threat to the public health, Lang et al. [16] intensively investigated the presence of enteropathogenic $E$. coli in marine water in the United States. They obtained 63 E. coli isolates from marine

* Author for correspondence: c/o Professor Kouichi Sano, Department of Microbiology, Osaka Medical College, 2-7 Daigakumachi, Takatsuki-shi, Osaka 569-8686, Japan. water from an outfall in California and 117 isolates from marine water from a closed estuary in North Carolina, and identified one enterotoxigenic E. coli strain and one STEC strain. However, they suggested that the infrequent detection of toxigenic E. coli indicates a low public health risk from the bacteria in coastal waters in the United States. In Japan, such survey of marine water has not yet been conducted. The $\mathrm{O} 157$ antigen-positive bacteria were confirmed by the fluorescent antibody technique from five rivers in and near metropolitan Tokyo in Japan [17]. We experienced a food-borne outbreak of STEC O157:H7 infection in Osaka prefecture, Japan, in $1996[18,19]$. STEC were also isolated from river waters in Osaka near the place of the outbreak [15]. Since the river drains into the Port of Osaka, we hypothesized that the bacterium can be found in marine water from the estuary Port of Osaka. To verify the hypothesis, we examined whether STEC can survive in marine water and whether it can be isolated from natural marine water samples. 


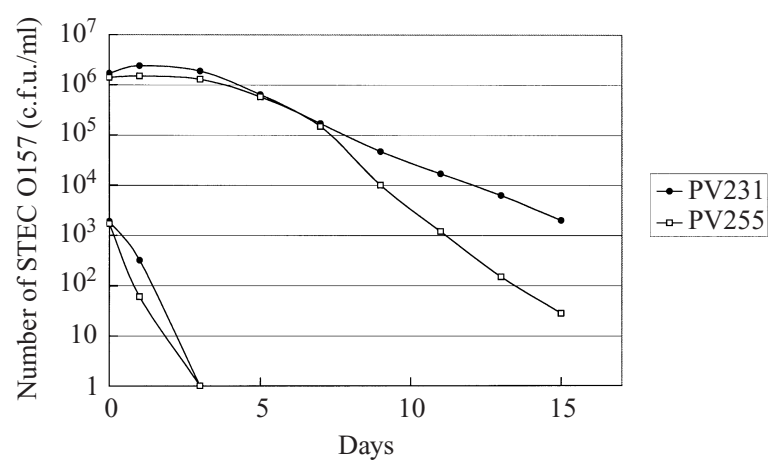

Fig. 1. Survival of STEC 157 in natural marine water. Two clinical strains of STEC O157, PV231 ( ) and PV255 ( $\square$ ), were inoculated in freshly collected natural marine water and incubated at $27^{\circ} \mathrm{C}$ for $1-15$ days.

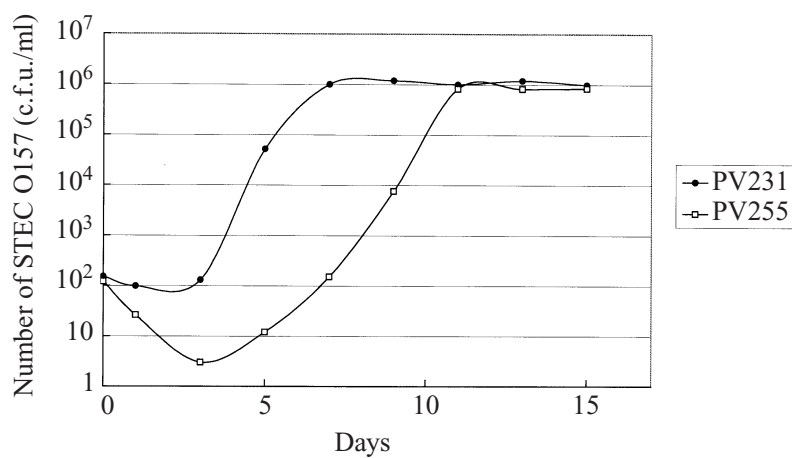

Fig. 2. Survival of STEC O157 in sterilized marine water. Two strains of STEC O157, PV231 ( ) and PV255 ( $\square$ ), were inoculated in sterilized marine water and incubated at $27^{\circ} \mathrm{C}$ for $1-15$ days.

Halotolerance and survival of STEC O157. Five strains of STEC O157 were examined for halotolerance. Clinical strains of STEC O157:H7, namely, PV231, PV255, PV216, PV354 and PV435, were cultured overnight at $37^{\circ} \mathrm{C}$ in $1 \%$ peptone water containing $0-8 \% \mathrm{NaCl}$.

To investigate the survival of STEC in natural marine water, marine water samples were obtained at $1-\mathrm{m}$ depth, approximately $5 \mathrm{~km}$ offshore the Port of Osaka, kept at room temperature, and processed within $3 \mathrm{~h}$. These marine water samples have a $\mathrm{pH}$ of 8.1 and contained $3 \% \mathrm{NaCl}$. Approximately $10^{3}$ and $10^{6}$ c.f.u. $/ \mathrm{ml}$ each of strains PV231 and PV255 were incubated in these marine water samples at $27^{\circ} \mathrm{C}$, which is the average natural temperature of marine water in summer, for 1-15 days. An aliquot of the marine water samples was inoculated onto plates of modified sorbitol MacConkey agar (CT-SMAC; Oxoid, Hampshire, England) containing $0.05 \mathrm{mg} / 1$ cefixim and $2.5 \mathrm{mg} / 1$ tellurous acid, incubated overnight at $37^{\circ} \mathrm{C}$; the colonies formed were then counted.
Stx production by the cultured bacteria was determined using a reverse passive latex agglutination (RPLA) test (VTEC-RPLA; Denka Seiken Co. Ltd, Tokyo, Japan). PCR assay for the Shiga toxin gene $(s t x)$ was performed using the marine water samples in which no viable STEC was detected by culture.

In order to eliminate the influence of other organisms inherent in marine water, this was autoclaved and approximately $10^{2}$ c.f.u./ $\mathrm{ml}$ of the bacteria were inoculated in this water and incubated at $27^{\circ} \mathrm{C}$ for 1-15 days. The culturable bacterial colonies were counted as described above.

Direct detection of the stx. We performed PCR for the stx and attempted to cultivate STEC in marine water samples collected from an estuary near the three rivers Aji, Kizu and Yamato, which drain into the Port of Osaka, from July to September in 1998 and 1999. A 1-1 water sample was collected in a sterile bottle monthly at each sampling site (2-3 km offshore each estuary). The sample was obtained at $1 \mathrm{~m}$ depth. These water samples were kept at room temperature and processed within $5 \mathrm{~h}$. The samples had a $\mathrm{pH}$ of $7 \cdot 2-8 \cdot 3$ and contained approximately $2 \% \mathrm{NaCl}$. The bacteria from the 1-1 water sample were trapped in $0.45 \mu \mathrm{m}$ membrane filters and were cultured in $250 \mathrm{ml}$ of mEC broth containing novobiocin (Kyokuto, Tokyo, Japan) for $15 \mathrm{~h}$ at $37^{\circ} \mathrm{C}$. The bacteria were concentrated in three different tubes using immunomagnetic beads coated with a O157-specific antibody (Dynabeads anti-E. coli O157; Dynal, AS, Oslo, Norway) [20] and the beads were resuspended in $0.1 \mathrm{ml}$ of buffer containing $10 \mathrm{mM} \mathrm{K}_{2} \mathrm{HPO}_{4}, 10 \mathrm{~mm}$ $\mathrm{KH}_{2} \mathrm{PO}_{4}, 100 \mathrm{~mm} \mathrm{NaCl}$ and $0.05 \%$ (w/v) Tween-20. The st $x$ in the suspension was amplified by PCR. A commercially available primer set (EVC-1 and EVC2; TaKaRa Biomedicals, Shiga, Japan), which recognized both st $x_{1}$ and st $x_{2}$, was used for screening. To differentiate between $s t x_{1}$ and $s t x_{2}$, commercially available primer sets (EVT-1 and EVT-2, EVS-1 and EVS-2; TaKaRa Biomedicals, Shiga, Japan) were used for amplification. The bacterial suspension was heated at $94{ }^{\circ} \mathrm{C}$ for $5 \mathrm{~min}$. Five microlitres of the suspension was mixed with $0.5 \mu 1$ each of the $20 \mathrm{~mm}$ dNTPs (Wako, Osaka, Japan), $0 \cdot 5 \mu 1$ each of the $19 \mathrm{pmol} / \mu \mathrm{l}$ primers, $1 \mu \mathrm{l}$ of $2 \mathrm{U} / \mu 1$ Tth DNA polymerase (Toyobo, Osaka, Japan), $37.5 \mu 1$ of distilled water and $5 \mu \mathrm{l}$ of $10 \times$ reaction mixture containing $15 \mathrm{~mm} \mathrm{MgCl}_{2}, 800 \mathrm{~mm} \mathrm{KCl}, 5 \mathrm{~g} / \mathrm{ml}$ bovine serum albumin, $1 \%$ sodium cholate and $1 \%$ Triton $\mathrm{X}-100$ in 100 mm Tris-HCl buffer (pH 8.9). Each PCR tube was heated as a predenaturation step at $94{ }^{\circ} \mathrm{C}$ for 
Table 1. Detection of $\mathrm{stx}_{1}$ and $\mathrm{stx}_{2}$ from marine water from the Port of Osaka in the last 2 years

\begin{tabular}{|c|c|c|c|c|c|c|}
\hline \multirow[b]{3}{*}{ Year } & \multicolumn{6}{|c|}{ Detection of stx $x_{1}$ and $s t x_{2}$ by PCR* } \\
\hline & \multicolumn{2}{|c|}{ River Aji estuary } & \multicolumn{2}{|c|}{ River Kizu estuary } & \multicolumn{2}{|c|}{ River Yamato estuary } \\
\hline & stx $x_{1}$ & st $x_{2}$ & stx $x_{1}$ & st $x_{2}$ & st $x_{1}$ & st $x_{2}$ \\
\hline \multicolumn{7}{|l|}{1998} \\
\hline July & - & - & - & - & - & - \\
\hline August & $2 / 3$ & $3 / 3$ & - & $3 / 3$ & - & - \\
\hline September & - & - & - & - & - & - \\
\hline \multicolumn{7}{|l|}{1999} \\
\hline July & - & - & - & $1 / 3$ & - & - \\
\hline August & - & - & - & - & - & - \\
\hline September & - & - & - & - & - & - \\
\hline
\end{tabular}

* Samples originated from three points in the port area were examined for the stx by PCR with common primer pair in triplicates. (-) indicates to be negative for st $x$ in the assay. The st $x$-positive samples were further examined for the st $x_{1}$ and st $x_{2}$ genes by the use of specific primer pairs to the respective genes. Numeral indicates positivity among triplicates.

$1 \mathrm{~min}$ in a thermal cycler (Thermo processor TR-100; Taitec Co., Tokyo, Japan). Specific DNA was amplified in the cycler for 35 thermal cycles at 94,55 and $75^{\circ} \mathrm{C}$ for $30 \mathrm{sec}$ each. The PCR products were analysed on a $1.5 \%$ agarose gel. A single band at $171 \mathrm{bp}$ was determined to be positive for the st $x$. The st $x$-positive samples were further examined for $s t x_{1}$ and $s t x_{2}$ in the same manner. Single bands at $349 \mathrm{bp}$ and $404 \mathrm{bp}$ were determined to be positive for the $s t x_{1}$ and $s t x_{2}$, respectively.

Isolation of STEC O157. The isolation of STEC O157 from a $25 \mu 1$ suspension of immunomagnetic beads in buffer was performed on CT-SMAC agar and sorbitol IPA bile agar (SIB; Kyokuto, Tokyo, Japan) plates. Approximately 50 colonies which do not ferment or slowly ferment sorbitol were confirmed by slide agglutination test using an $\mathrm{O} 157$ antiserum (Denka Seiken Co. Ltd, Tokyo, Japan).

In order to clarify whether STEC O157 is halotolerant, we examined the growth of the bacteria in the presence of $\mathrm{NaCl}$. Three strains, PV216, PV255 and PV354, showed halotolerant growth in $6 \% \mathrm{NaCl}$ in peptone water and two strains, PV231 and PV435, in $5 \% \mathrm{NaCl}$ after overnight incubation at $37{ }^{\circ} \mathrm{C}$. Since the concentrations of $\mathrm{NaCl}$ in the medium used for the halotolerance test are higher than those in marine water, STEC O157 may survive in natural marine water. To investigate whether STEC O157 can survive for a long term in the natural marine environment, two strains, PV231 and PV255, were inoculated at approximate $10^{6}$ c.f.u. $/ \mathrm{ml}$ in natural marine water and incubated at $27^{\circ} \mathrm{C}$. When approximately $10^{6}$ c.f.u. $/ \mathrm{ml}$ of the bacteria were inoculated, the number of culturable bacteria decreased, however, approximately $10-10^{3}$ c.f.u. $/ \mathrm{ml}$ of STEC $\mathrm{O} 157$ were still culturable by the 15th day of incubation (Fig. 1). The bacterial production of Stx was confirmed by RPLA test (data not shown). Furthermore, we examined the bacterial growth in marine water in the absence of natural biological competitors, such as protozoae, using sterilized marine water. Both bacterial strains, PV231 and PV255, increased in number up to $10^{6}$ c.f.u./ml 7-10 days after incubation (Fig. 2). The results above suggest that STEC may survive long-term exposure to marine water in the absence of biological competitors.

We attempted the detection of STEC O157 in natural marine water. Since we could detect the st $x$ by PCR in the water samples collected from the estuary of the Port of Osaka near the rivers Aji and Kizu in August 1998, and River Kizu in July 1999, we further analysed the same positive samples for the presence of $s t x_{1}$ and $s t x_{2}$. The st $x_{1}$ was detected in samples collected from the River Aji estuary in 1998, and the st $x_{2}$ was detected in samples collected from the estuaries of rivers Aji and Kizu in 1998 and in samples collected from the River Kizu estuary in 1999 (Table 1, Fig. 3). We could not confirm the presence of culturable STEC O157 among the isolated colonies by the slide agglutination test (data not shown). This discrepancy between the presence of the stx and absence of culturable STEC is explained as follows: (1) The sensitivity of PCR assay $\left(10^{4}\right.$ c.f.u. $/ \mathrm{ml}$; data not shown) was sufficient to detect the stx, but the sensitivity of the culture method $\left(10^{5}-10^{6}\right.$ c.f.u. $/ \mathrm{ml}$; data not shown) was insufficient to isolate the 


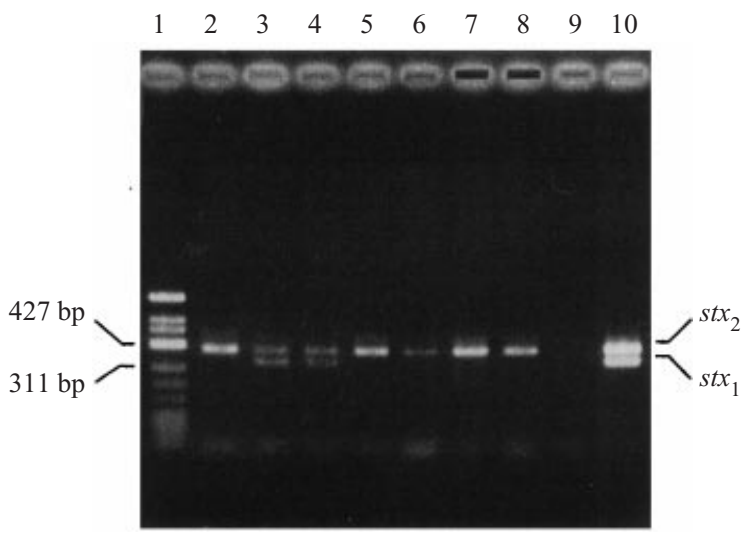

Fig. 3. Representative electrophoretograph of PCR products amplified using primer pairs for st $x_{1}$ and $s t x_{2}$. To obtain the DNA bands corresponding to st $x_{1}$ and st $x_{2}$ in an agarose gel, $5 \mu \mathrm{l}$ each of the PCR products of st $x_{1}$ and st $x_{2}$ were mixed with $4 \mu \mathrm{l}$ of loading buffer. Ten microlitres of the final mixture was loaded on a $1.5 \%$ agarose gel and electrophoresed for $35 \mathrm{~min}$ at $100 \mathrm{~V}$. Lane 1 contains molecular size markers $(\varnothing \times 174 \mathrm{RF}$ I/Hinf $\mathrm{I})$. Lanes $2-10$ are specific PCR products amplified by primer pairs for st $x_{1}$ and st $x_{2}$; lanes 2-4 are samples from the River Aji estuary collected in August 1998. Lanes 5-7 are samples from the River Kizu estuary collected in August 1998 and lane 8 is the sample from the same place collected in July 1999. Lanes 9 and 10 are the negative and positive controls, respectively.

bacterium; (2) The beads may capture the sorbitolfermenting STEC O157 [21] or viable but nonculturable (VNC) state STEC O157 [22]; and (3) The beads may also capture other $\mathrm{O} 157$ antigen-positive bacteria, such as the stx-positive Citrobacter freundii [23]. A small number, approximately $10^{3}$ c.f.u. $/ \mathrm{ml}$, of bacteria that were experimentally incubated in natural marine water could not be recovered as culturable bacteria (Fig. 1), and also the stx could not be detected from the water by PCR (data not shown) in this study. These results may indicate that the stxpositive marine water contained viable st $x$-positive bacteria.

We were not able to isolate STEC, however, the genes of stx are frequently detected in Japan. In order to clarify the origin of the st $x$ in marine water, another survey of marine water for STEC and/or other stxpositive bacteria should be conducted. Since we did not perform the examination of VNC state bacteria in this study, the other study for VNC may be required in the survey. If STEC is isolated in the survey, we should determine whether the bacterium is present in routes of transmission to humans. When other bacteria bearing the genes of st $x$ are isolated, they should be studied to determine if they are pathogenic to humans.

\section{ACKNOWLEDGEMENTS}

We thank Dr Y. Kusui, Mr N. Tanoda, Mr M. Matsuo, Mr K. Toguchi, Mr T. Yagi and Ms K. Mori of the Osaka Quarantine Station for their technical help, and Drs T. Kohno, T. Nakano, T. Goto and C. Morita of the Department of Microbiology, Osaka Medical College for their technical advice.

\section{REFERENCES}

1. Paton AW, Ratcliff RM, Doyle RM, et al. Molecular microbiological investigation of an outbreak of hemolytic-uremic syndrome caused by dry fermented sausage contaminated with Shiga-like toxin-producing Escherichia coli. J Clin Microbiol 1996; 34: 1622-7.

2. Wells JG, Shipman LD, Greene KD, et al. Isolation of Escherichia coli serotype O157:H7 and other Shiga-like toxin-producing $E$. coli from dairy cattle. J Clin Microbiol 1991; 29: 985-9.

3. Center for Disease Control. Outbreak of Escherichia coli $\mathrm{O} 157: \mathrm{H} 7$ infections associated with drinking unpasteurized commercial apple juice - British Columbia, California, Colorado, and Washington, October 1996. MMWR 1996; 45: 975.

4. Infectious Disease Surveillance Center, National Institute of Infectious Diseases. Enterohemorrhagic Escherichia coli (verocytotoxin-producing E. coli) infection, 1996-April 1998. IASR 1998; 19: 122-3.

5. Asai Y, Murase T, Osawa R, et al. Isolation of Shiga toxin-producing Escherichia coli O157:H7 from processed salmon roe associated with the outbreaks in Japan, 1988, and a molecular typing of the isolates by pulsed-field gel electrophoresis. J Japan Associat Infect Dis 1999; 73: 20-4.

6. Dev VJ, Main M, Gould I. Waterborne outbreak of Escherichia coli O157. Lancet 1991; 337: 1412.

7. Swerdlow DL, Woodruff BA, Brady RC, et al. A waterborne outbreak in Missouri of Escherichia coli O157:H7 associated with bloody diarrhea and death. Ann Inter Med 1992; 117: 812-9.

8. Conedera G, Marangton S, Chapman PA, Zuin A, Caprioli A. Atypical strains of Verocytotoxin-producing Escherichia coli $\mathrm{O} 157$ in beef cattle at slaughter in Veneto region, Italy. J Vet Med 1997; 44: 301-6.

9. Chaoman PA, Siddons CA, Cerdan Malo AT, Harkin MA. A 1-year study of Escherichia coli O157 in cattle, sheep, pigs and poultry. Epidemiol Infect 1997; 119: 245-50.

10. William EK, McAnulty JM, Hoesly FC, et al. A swimming-associated outbrake of haemorrhagic colitis caused by Escherichia coli O157:H7 and Shigella sonnei. New Eng J Med 1994; 331: 579-84.

11. Centers for Disease Control. Lake-associated outbreak of Escherichia coli O157:H7-Illinois, 1995. MMWR 1996; 45: 437-9.

12. Ackman D, Marks S, Mack P, Caldwell M, Root T, Birkhead G. Swimming-associated haemorrhagic colitis 
due to Escherichia coli O157:H7 infection: evidence of prolonged contamination of a fresh water lake. Epidemiol Infect 1997; 119: 1-8.

13. Brewster DH, Brown MI, Robertson D, Houghton GL, Bimson J, Sharp JC. An outbreak of Escherichia coli O157 associated with a children's paddling pool. Epidemiol Infect 1994; 112: 441-7.

14. Hildebrand JM. An outbreak of Escherichia coli O157 infection linked to paddling pools. CDR Rev 1996; 6: R33-6.

15. Sakai City. Survey results of Escherichia coli O157 in a public water area. Environment of Sakai in 1998, 1999.

16. Lang AL, Tsai UL, Mayer CL, Patton KC, Palmer CJ. Multiplex PCR for detection of the heat-labile toxin gene and shiga-like toxin I and II genes in Escherichia coli isolated from natural waters. Appl Environ Microbiol 1994; 60: 3145-9.

17. Kogure K, Ikemoto E. Wide occurrence of enterohemorrhagic Escherichia coli O157 in natural fresh water environment. Jpn J Bacteriol 1997; 52: 601-7.
18. WHO. Enterohaemorrhagic Escherichia coli infection. Weekly Epid Rec 1996; 71: 267-8.

19. Infectious Agents Surveillance Center, National Institute of Health. Outbreaks of enterohemorrhagic Escherichia coli O157:H7 infection, 1996, Japan. Jpn J Med Sci Biol 1996; 49: 40-1.

20. Olsvik Ø, Popovic T, Skjerve E, et al. Magnetic separation techniques in diagnostic microbiology. Clin Microbiol Rev 1994; 7: 43-54.

21. Gunzer F, Bohm H, Russmann H, et al. Molecular detection of sorbitol-fermenting Escherichia coli in patients with hemolytic-uremic syndrome. J Clin Microbiol 1992; 30: 1807-10.

22. Xu H-S, Roberts N, Singleton FL, Attwell RW, Grimes DJ, Colwell RR. Survival and viability of nonculturable Escherichia coli and Vibrio cholerae in the estuarine and marine environment. Microb Ecol 1982; 8: 313-23.

23. Schmidt H, Montag M, Bockemuhl J, Heesemann J, Karch H. Shiga-like toxin II-related cytotoxins in Citrobacter freundii strains from humans and beef samples. Infect Immun 1993; 61: 534-43. 